\title{
The Meaning of Actor Social Action in Distribution of Subsidized Fertilizers in Pulang Pisau District, Central Kalimantan Province
}

\author{
Baini $^{1}$, Ishomuddin ${ }^{2 *}$, Rinikso Kartono ${ }^{3}$, Tri Sulistyaningsih ${ }^{4}$ \\ ${ }^{1}$ Doctor Candidate of Social and Political Sciences of University of Muhammadiyah Malang \\ ${ }^{2}$ Professor of Sociology of Islamic Society of University of Muhammadiyah Malang, \\ ${ }^{3}$ Doctor of Social Welfare of University of Muhammadiyah Malang \\ ${ }^{4}$ Doctor of Sociology of University of Muhammadiyah Malang
}

*Corresponding Author: Ishomuddin, Doctor Candidate of Social and Political Sciences of University of Muhammadiyah Malang, Indonesia

\begin{abstract}
Government policies on subsidized fertilizers as well as the distribution of subsidized fertilizers have been carried out comprehensively starting from the preparation of fertilizer demand plans, the highest ecera price of subsidized fertilizers, distribution systems from producers to farmers or farmer groups. But apparently there are still some problems found in the field, namely the lack of fertilizer supply, causing a shortage of stock which resulted in a surge in subsidized fertilizer HET, and still found the distribution of subsidized fertilizer that is not on target as stated in the RDKK. Some of the causes of the above problems are (a) problems in preparing RDKK, (b) differences in fertilizer prices (disparities), (c) unrealistic supplier margins $(d)$ limited subsidized fertilizer budgets, and (e) less optimal supervision. From this phenomenon, the purpose of this study is to understand the meaning of social actions of actors in the distribution of subsidized fertilizer in Pulang Pisau Regency, Central Kalimantan Province. This study uses a qualitative approach to the type of phenomenological research. Data collection techniques are done by observation, interview and documentation study. While the data analysis technique uses the Stake model that is collecting categories, direct interpretation, forming patterns and naturalistic generalizations through data analysis.
\end{abstract}

Keywords: Meaning, Social Action, Actor, Distribution, Subsidized Fertilizer

\section{INTRODUCTION}

Subsidized fertilizer policy is a government policy in agriculture in order to strengthen food security which has scope and targets that are always changing from year to year. In addition, the subsidized fertilizer distribution system has also undergone changes and improvements through a card control system and a system of direct subsidies to farmer groups so that it is more directly on target (Rachman, 2012). But apparently there are still some problems in the field, namely the lack of fertilizer supply which causes scarcity of stocks which results in a jump in the highest retail price of subsidized fertilizer, as well as the distribution of subsidized fertilizers that are not on target as stated in the Definitive Plan for Group Needs. Problems like this continue to be repeated every year (Rachman, 2012). Some of the causes of the above problems according to Rachman (2009) and Hadi et al. (2010) are (a) the problem of preparing the Definitive Needs of Group Needs, (b) differences in fertilizer prices (disparities), (c) unrealistic supplier margins (d) limited subsidized fertilizer budgets, and (e) less optimal supervision (Rachman, 2012).

The deviations should not occur in the distribution of subsidized fertilizer, because the subsidized fertilizer policy is regulated in the Regulation of the Minister of Agriculture of the Republic of Indonesia Number 69/Permentan/SR.310/12/2016 concerning the Allocation and Highest Retail Price of Subsidized Fertilizers for the Agricultural Sector 2017 budget year. Deviance is a form of behavior of individuals that is not in accordance with the norms and rules of society. As Weber argues that humans are personally individuals who do not want to be quiet and are always creative, whereas social reality is always dynamic as a means of curbing social facts. Thus every thing that is done by individuals is not solely due to habits, values and norms as referred to in social facts. Nevertheless, Weber finally understood that in the life of a society there is a social structure or social structure and 
The Meaning of Actor Social Action in Distribution of Subsidized Fertilizers in Pulang Pisau District, Central Kalimantan Province

social institutions. Therefore, every social action is always influenced and shaped by social structures and social institutions (Wirawan, 2013).

Weber (Ritzer, 2001) specifically classifies social actions that have subjective meanings into four types. On the basis of the rationality of social action, Weber distinguishes human social action into four types, the more rational social action is more easily understood: 1) instrumental rationality (zwerkrational), 2) value rational action (werkrational), 3) affective action (affectual action ), and 4) traditional actions. From Weber's theory, if it is related to human social action in the distribution of subsidized fertilizer in Pulang Pisau Regency, it is included in the type of instrumental rationality (zwerk rational). This can be seen from the indication of scarcity of subsidized fertilizer by landfilling, which is a form of awareness of the perpetrators with consideration of increasing fertilizer prices, as well as a price disparity that is rationally understood and calculated to be materially beneficial to the offender.

Thus in the context of the occurrence of irregularities in the distribution of subsidized fertilizer based on Weber's social action theory it can be said that each individual actor's actions have meaning in carrying out deviations. From this phenomenon, the purpose of this study is to understand the meaning of social actions of actors in the distribution of subsidized fertilizer in Pulang Pisau Regency, Central Kalimantan Province.

\section{CONCEPTUAL FraMeWORK}

\subsection{Actions and Meanings}

Actions have several levels, namely: (a) perception, that is, knowing and choosing various objects to be carried out, (b) guided responses that do everything in the right order, (c) the mechanism of doing things correctly automatically, and (d ) adaptation is a practice or action that has been developed and performed well (Notoatmodjo, 2007). In action theory, Parsons explains that actors act to achieve a certain goal. Actors' actions are influenced by a variety of factors, namely the availability of tools, the conditions that impede, the prevailing norms, and the cultural system in which the actor is located. In Parsons's view, as explained by Turner, Action involves actors making subjective decisions about the means to achieve goals, all of which are constrained by ideas and situational conditions. (Turner, 1998) Likewise Parsons' theory of pattern variables, where Parsons explains two patterns of action, namely expressive and instrumental actions (Kinseng, 2004).

In an individual or group action contained both implied and explicit meaning. Max Weber in introducing the concept of the verstehen approach to understanding the meaning of one's actions, assumes that a person in acting does not merely implement it but also places himself in the environment of other people's thinking and behavior. The concept of this approach is more directed to an action patterned on the objectives to be achieved (Wirawan, 2013). In an individual action contained meaning that is the purpose of these actions. Borrow a quote from Warinner that Weber explains that: meaning (Sinn) is something inherent in the act itself, a property of the act rather than a cause or purpose (meaning is something that is inherently contained in the action itself, is an action property of just as a cause or purpose) (Supraja, 2012).

Saussure expresses meanings as meanings or concepts that are owned or contained in a linguistic sign. If someone interprets the meaning of a symbol, it means that he thinks properly about the symbol; namely a desire to produce certain answers with certain conditions as well (Sarnia, 2015). Based on Saussure's opinion, the deviation in the distribution of subsidized fertilizer has various meanings. The meaning of irregularities in the distribution of subsidized fertilizers can be interpreted in terms of the quantity (amount) of fertilizer distributed, in terms of the object (target) that receives subsidized fertilizer, and can also be seen in terms of the subject (implementing) or distributor of subsidized fertilizer.

According to Brodbeck (Sobur, 2015) that there are actually three notions of the concept of different meanings: (1) referential meaning ie the meaning of a term is the object, thought, idea or concept shown by the term, (2) the meaning of the term. A term can have a reference meaning in the first sense, which is to have a referent, but because it is not associated with various other concepts, it has no meaning, and (3) the intended meaning (intentional) in the sense that the meaning of a term or symbol depends on what the user means by the meaning of the symbol. Based on Brodbeck's opinion, 
the meaning of social action in the distribution of subsidized fertilizer means that there is an idea or concept of action taken by an individual or group of people who have a specific purpose or goal. The purpose and objectives of the individual or group of people are manifested in the form of actions relating to the distribution of subsidized fertilizer.

\subsection{Distribution Deviations}

Bagong and Narwoko (2004), explained several criteria that can be categorized as deviant actions, namely: (1) nonconforming actions, namely behavior that is not in accordance with existing values and norms, (2) antisocial actions namely actions that oppose habits public or public interest, and (3) criminal actions, ie acts that clearly violate written legal rules and threaten the life or safety of others.

Setiadi and Usman (2011) explained that in general the form of deviant behavior can be divided into two, namely: (a) positive deviations are deviations directed at ideal social values (coveted) even though the way or action taken is as if appear to deviate from the prevailing norms, when in fact it is not deviant, (b) negative deviations are the tendency to act toward social values that are considered inferior and consequently always bad. In addition, Horton (Setiadi and Usman, 2011) argues that there are six characteristics of deviant behavior, including: (a) deviations must be defined, i.e. the behavior has indeed been labeled as a deviation because it harms many people or causes unrest in society, despite the fact that not all deviant behavior harms others. The guiding basis is the values and norms recognized by the majority of the majority, so that if there are behaviors that are not in line with the values and norms of the majority subjects of the community, then the behavior is said to be deviant, (b) deviations can be accepted or rejected, meaning that not all deviant behavior is considered negative, but there are times when deviant behavior actually gets praise, (c) relative deviations and absolute deviations, meaning that no human fully behaves in a straight line with social values and norms (conformist) or completely deviant behavior. Benchmarks used to determine whether deviant actions are categorized as absolute or relative deviations are the frequency of deviations committed, (d) deviations from real and ideal culture, meaning that an actual action when viewed from the culture prevailing in the structure of society is considered conform, but by positive law regulations are considered deviations, (e) there are norms of avoidance in deviations, the intention is the pattern of actions carried out by people to fulfill their desires without having to oppose values and norms but actually the acts are against norms, and (f) social deviations are adaptive (adjustment), meaning that this action does not pose a threat of social disintegration, but rather is needed to maintain social integrity. Social dynamics is a product of social processes that cannot be avoided by anyone.

Vembriarto (1984) explains that viewed from the aspect of its function, deviations are divided into three types, namely: (1) individual deviations are deviations originating from factors in the individual, for example illness, traits, and accidents, or caused by socio-cultural influences that are is unique to a person, (2) situational deviations are deviations due to the influence of the forces of the situation outside a person or in conditions where a person is an integral part of a situation, and (3) a systematic deviation is an organized deviation that is a deviation of behavior in organizations related to morals, roles, norms and status of a culture or habits of society.

\subsection{Theory of Social Action}

According to Johnson (Upe, 2008) that social action is an action that has a subjective meaning for and from the culprit actor. So that social action is not accidental behavior but which has certain patterns and structures and certain meanings. Hinkle's theory of action (Upe, 2008), has fundamental assumptions, namely: (1) actions taken by humans arise because of their own awareness as subjects and because of external situations in their position as objects, (2) humans as subjects act / behave in order to achieve certain desired goals, (3) human beings act by means of procedural techniques, methods and tools that are tailored to the objectives to be achieved, (4) humans in choosing, evaluating, and evaluating each of their actions both after and before, and (5) in taking human decisions are expected to rely on the size, rules or moral principles that exist in society.

Parsons (Ritzer, 2005) specifically made a schema of the basic unit characteristics of each social action namely: (1) the individual as an actor, (2) the actor is the hunter for the objectives to be achieved, (3) the actor has ways, alternatives, tools, and techniques to achieve its objectives, (4) actors are limited by certain situations and conditions in order to achieve their goals, and (5) actors always 
use values, norms and rules as a basis for choosing and determining their goals. Each actor in pursuing the desired goal will rely on norms, values and rules even though the final decision lies in the ability of the actor in choosing alternative tools and methods. The ability of actors to choose alternative ways and tools is called voluntarism, namely the ability to choose tools and ways to achieve the desired goals.

The theory used in this analysis intends to understand how social action towards acts of deviation in the distribution of subsidized fertilizers is the theory of Max Weber. In his theory of action, Weber's goal is nothing but focusing attention on individuals, patterns and regularity of action, not on collectivity. Actions in terms of behavioral orientation that can be understood subjectively are only present as the behavior of one or several individual human beings (Ritzer \& Goodman, 2007).

Social action for Weber is an individual action as long as the action has a meaning or subjective meaning for himself and directed to the actions of others (Ritzer, 1975). An individual action directed at inanimate objects is not included in the category of social action. Social actions are actions that are clearly directed at others. Social actions can be in the form of mental or subjective actions that may occur due to the positive influence of a particular situation or are acts of deliberate repetition as a result of the influence of similar situations or in the form of passive agreement in certain situations (Turner, 2000).

According to Weber (Ritzer, 1975 and Turner, 2000) there are five main characteristics that include social action, namely: (1) if the human action according to the actor contains a subjective meaning and this can include a variety of real actions, (2) real actions that can be think in full, (3) the action can originate from the effect of a positive influence on a situation, an act that is intentionally repeated, or an action in the form of a tacit agreement from any party, (4) the action is directed at a person or at several individuals, and (5) those actions pay attention to the actions of others and are directed at the other person.

Based on Weber's theory, we can know each individual or group action based on certain motives of each action taken. Weber's theory can be used to know and understand the types of behavior of human action both as individuals and groups so that they can understand their reasons for acting. As Weber said that to understand groups is to respect the typical forms of actions or behaviors as characteristics, so that they know the reasons for the community to act (Jones, 2003).

On the basis of the rationality of social action, Weber (Ritzer, 2001) distinguishes it in four types, where the more rational social action is more easily understood, the four types are: (a) zwerk rational, namely pure social action. In this action the actor not only assesses the best way to achieve his goal but also determines the value of the goal itself, (b) wer rational action, in this type of action the actor cannot judge whether the methods chosen are the most appropriate for achieve another goal. In this action indeed between the goals and ways to achieve them tend to be difficult to distinguish, but this action is rational because the choice of ways has determined the desired goals, (c) affectual action, is a made-up action, influenced by emotional feelings and the pretense of the actor. These actions are difficult to understand lacking or irrational, and (d) traditional actions, actions that are based on habits in doing something in the past only.

Furthermore Turner (2012) explains that the typology of actions by Weber shows that the actors have the characteristics and characteristics of each as a form of feelings and conditions from within the actor's personality that are manifested in the form of actions. The existence of an actor's actions shows the ability possessed by the actor, although each actor does not only have one type but can have two types or a combination of these types of actions so that he has an orientation in each of his actions.

\section{Methodology}

\subsection{Research Paradigm}

This study uses the social definition paradigm. The social definition paradigm is one of the very special aspects of Weber's work, namely in his analysis of social action. What is meant by social actions are individual actions as long as their actions have meaning or subjective meaning for themselves and are directed towards others. In this sense two basic concepts are contained; First, the concept of social action, and second, the concept of interpretation and understanding. The second 
The Meaning of Actor Social Action in Distribution of Subsidized Fertilizers in Pulang Pisau District, Central Kalimantan Province

concept concerns a method for explaining the first (Ritzer, 2007). In understanding social actions in the process of distribution of subsidized fertilizers will be analyzed using the perspective of social action theory so that it is easy to analyze the meaning of social actions by actors in the distribution of subsidized fertilizers.

\subsection{Research Approach}

The research approach in this study is a qualitative approach. Tracy (2013) qualitative research is a research method that explores an understanding of the significance of an event or experience of a person or group. In qualitative research, researchers as a key instrument conduct in-depth research by exploring a problem to explore knowledge and see a meaningful process of social action of actors in the distribution of subsidized fertilizers.

\subsection{Types of Research}

This type of research is phenomenology research. Phenomenology seeks to understand how humans construct important meanings and concepts within the framework of intersubjectivity (Kuswarno, 2009). Phenomenology assumes everyone is active in interpreting his experiences and trying to understand the world with his personal experience (Littlejohn, 2009).

Phenomenology research focuses on intentionality, which is something experienced by the individual consciously, so that a relationship between an action or behavior with the object of that action is based on consciousness. So that every action carried out by individuals is always based on awareness of an object. Individual intentionality is not only related to the purpose of action on a particular object, but also related to the character and thoughts of something that has an object. Therefore this study wants to understand the meaning of social actions of actors in the distribution of subsidized fertilizers.

\subsection{Research Subjects}

According to Miles and Huberman (1984), there are several criteria used in determining research subjects, namely setting, actors, events, and processes. Criteria setting is the condition and situation of the location of the collection of research data. The actor criterion is the person who distributes and receives subsidized fertilizer. The event criteria is the distribution of subsidized fertilizer. Process criteria are the occurrence of questions and answers between interviewers and informants, participatory observation activities and other activities that can find data at the research location. Criteria for research subjects in the study of the meaning of social actions of actors in the distribution of subsidized fertilizers are: (1) actors involved in the process of distribution of subsidized fertilizers, (2) actors who know and understand the process of distribution of subsidized fertilizers, and (3) actors who are willing to provide data and information relating to the process of distribution of subsidized fertilizers. The research subjects or informants consisted of producers, fertilizer distributors, fertilizer retailers, farmer groups/farmers, field agriculture instructors, and the Fertilizer and Pesticide Monitoring Commission.

\subsection{Data Analysis}

In qualitative research, data analysis activities begin since the researcher makes observations on the activities and conditions of the research object until data collection, compilation and processing and drawing conclusions from the end of the study, then according to the opinion of Stake in Cresswell (1998), the step of data analysis of this study are: (1) collection of categories, carried out by collecting data about the process of distribution of subsidized fertilizers by comparing the Definitive Plan for Group Needs with the amount of subsidized fertilizer distributed, (2) direct interpretation, carried out by making direct observations of the distribution process from producers to The distributor then observes the distribution from the distributor to the retailer to the farmer group or farmer group combination, so that a point where the distribution of subsidized fertilizer distribution can be found, (3) the researcher forms a pattern and looks for a match between two or more categories. ri. This is done by comparing the findings with the Definitive Plans of Group Needs so that there is a difference in quantity that is possible for distortion of distribution, and (4) in the end, the researcher develops naturalistic generalizations through data analysis. Done by analyzing the results of data collection derived from interviews, observations and documentation studies to be processed and analyzed so that it can find answers to the meaning of the social actions of actors in the distribution of subsidized fertilizer, which in turn can be drawn a conclusion. 
The Meaning of Actor Social Action in Distribution of Subsidized Fertilizers in Pulang Pisau District, Central Kalimantan Province

\section{RESULTS AND DISCUSSION}

After the researchers conducted observations, interviews and documentation of the actors willing to provide data and information related to the process of distribution of subsidized fertilizers, the researchers compiled reports and presented research data. Presentation of research data is done by the researcher describing in the form of a description based on the results of observations, interviews and documentation simultaneously whose data supports each other and is related to the behavior experienced by the research subject actors. To that end, researchers describe the meaning of the social actions of actors in the distribution of subsidized fertilizers in accordance with Weber's social action theory as follows:

\subsection{Rational Actions}

Based on this type of social action, producers (PT. Pupuk Kaltim and PT. Pupuk Kimia Gresik) and Distributors (PT. Pertani Persero and PT. Goautama Sinar Batuah) have an awareness that they have the ability or capacity to distribute subsidized fertilizers. This means that the distribution of subsidized fertilizers must reach the retailers and farmer groups in accordance with the six principles namely right place, right price, right quality, right type, right amount and on time. If there are distributors or retailers who commit irregularities in the distribution of subsidized fertilizer, fertilizer producers can act firmly and hand it over to the authorities. Thus the producers (PT. Pupuk Kaltim and PT. Pupuk Kimia Gresik) understand that there can be irregularities in the distribution of fertilizers, so they think rationally and consciously of ways to avoid irregularities in subsidized fertilizers according to their capacity of authority, through the Farmer Card System and the Definitive Plan for Group Needs.

In terms of authority capacity, producers can terminate cooperation with distributors if they commit irregularities or abuse in the distribution of subsidized fertilizers. Likewise the distributor can also stop his cooperation with retailers by not giving rations to retailers. One reason for using this type of rational action is because of the capacity of producers (PT. Pupuk Kaltim and PT. Pupuk Kimia Gresik) and Distributors (PT. Pertani Persero and PT. Goautama Sinar Batuah) who have the ability to produce subsidized fertilizers and the ability to distribute subsidized fertilizer both in terms of production sites and distribution facilities.

In analyzing the meaning of social actions of actors in the distribution of subsidized fertilizers by using rational action types, it can be seen the capacity or ability of producers (PT. Pupuk Kaltim and PT. Pupuk Kimia Gresik) and Distributors (PT. Pertani Persero and PT. Goautama Sinar Batuah). Actors (producers and distributors) consciously and planned have the capacity to produce and distribute subsidized fertilizers while still maintaining the six principles of distribution.

\subsection{Value Rationality Actions}

The type of value rationality underlies the actions of actors based on values that are understood and carried out by actors. The value understood by the actors in this case producers and distributors is to produce subsidized fertilizer in accordance with the conditions set by PT. Indonesian Fertilizer as a party appointed by the Indonesian government through the Ministry of Agriculture to provide subsidized fertilizers of Urea, ZA, SP-36, NPK and Organic types. In carrying out this task, PT. Pupuk Indonesia appointed PT. Pupuk Kaltim and PT. Gresik Chemical Fertilizer as a producer of subsidized fertilizer so it must produce subsidized fertilizer in accordance with the principle of six right. In this condition, the principle of six precisely becomes the value and indicator for PT. Pupuk Kaltim and PT. Gresik Chemical Fertilizers in producing subsidized fertilizers.

With principles based on the right six, the actors (producers and distributors) can carry out their duties and responsibilities, so that a production system that is of the right quality, the right type, the right amount and the right time is realized. While distributors can realize that value in the form of on time, right amount, right price and right place to distribute subsidized fertilizer to retailers. However, this type of value rationality is not done by distributors because fertilizer that is distributed is sometimes not timely because it is not right in the growing season. Likewise, retailers who still override the value of service, because they are still profit-oriented, so that they deny the principle of the right price and the right place because subsidized fertilizer is not delivered to the farmer groups but must be taken at the retailer's warehouse. 
The Meaning of Actor Social Action in Distribution of Subsidized Fertilizers in Pulang Pisau District, Central Kalimantan Province

\subsection{Affective Actions}

Affective type shows an actor's behavior or actions based on emotional considerations or orientations of the actor (actor). As the actions of distributor actors who charge transportation fees to move subsidized fertilizer from distribution trucks to retailers' warehouses. This emotional action was carried out because the distributor did not have the cost to pay for the labor that moved the subsidized fertilizer from the truck to the retailer's rear warehouse. So this emotional feeling to collect additional costs is based on the consideration of the absence of labor to move subsidized fertilizer to the retailer's warehouse.

In addition to the emotional attitude of the distributor, there is also an affective action taken by the retailer, namely levies on farmer groups who ask to be delivered to subsidized fertilizer to the farmer groups. The reason used is for transportation costs. Farmer groups are charged ten thousand rupiah per bag of fertilizer.

Based on the actions of the distributor or retailer actor, we can find out the consideration or orientation of the emotional attitude of the distributor or retailer so that they charge extra fees. Thus, the levies carried out by distributors and retailers have the meaning of deviations from the six principles of distribution, especially right on price, even though they mean only as a transportation cost or a substitute for transportation costs.

\subsection{Traditional Actions}

Traditional actions assume that each actor's actions are based on habits or traditions that live in the community. In fertilizer distribution, increasing prices or reducing the number of scales is sometimes considered normal because for operations to weigh, deliver and even wrap, so that if there is a difference in price between producer and distributor prices with retailers prices are considered normal and normal. In addition, to get subsidized fertilizer rations by giving money to retailers it is also considered normal so that later they get priority fertilizer rations.

If raising the price of fertilizer by a retailer is considered a tradition then it is an obligation and duty of the Fertilizer and Pesticide Supervision Commission to conduct surveillance and enforcement and report it to the authorities. Deviations to increase prices occur because of differences in prices between subsidized and non-subsidized fertilizer that is so large, namely Rp. 160,000 per sack (50 kilograms) or Rp. 3,200 per kilogram, so retailers want to benefit from the price difference.

Thus, an analysis based on the traditional type of action can be said that deviations in the form of increasing the selling price of subsidized fertilizer and collecting transport costs, the cost of transporting fertilizer to the place of the farmer group is considered normal. So that it can be known the motives and goals of distributors and retailers in raising prices and collecting other costs, namely wanting to find or increase profits in the sale of subsidized fertilizer in each planting season. The actions of distributors and retailers interpreting irregularities in raising prices are considered normal or reasonable as a form of irregularities in the distribution of subsidized fertilizer in Pulang Pisau Regency, Central Kalimantan Province.

\section{CONCLUSION}

Based on the results of the study, it can be concluded that Weber's social action theory in relation to the actions of actors in the distribution of subsidized fertilizers in Pulang Pisau Regency, Central Kalimantan Province has different meanings according to its type, namely: (1) the type of rational action is interpreted as the actions of actors (producers and distributor) to properly distribute subsidized fertilizer based on the six principles, (2) the type of value rationality is interpreted as an act of the actors (producers and distributors) in producing and distributing fertilizers in accordance with government policies based on the values of the six principles right, (3) the affective types of the actions of the actors (distributors and retailers) in carrying out distribution deviations are interpreted based on emotional considerations and profit-oriented, and (4) the traditional types of actions of the actors (distributors and retailers) in the distribution deviations are interpreted as normal or natural.

\section{REFERENCES}

[1] Bagong, Suyanto dan Narwoko, J. Dwi. (2004). Sosiologi Teks Pengantar dan Terapan. Jakarta: Kencana Media Group.

[2] Creswell, J. W. (1998). Qualitative Inquiry And Research Design: Choosing A Mong Five Tradition. London: Sage Publication. 
The Meaning of Actor Social Action in Distribution of Subsidized Fertilizers in Pulang Pisau District, Central Kalimantan Province

[3] Jones, Pip. (2003). Pengantar Teori-Teori Sosial: Dari Teori Fungsionalisme Hingga Post Modernisme, (trj.) Saifuddin. Jakarta: Pustaka Obor.

[4] Kinseng, R. A. (2004). Struktugensi: Sebuah Teori Tindakan (Structugency: A Theory of Action). Sodality: Jurnal Sosiologi Pedesaan. Agustus 2017, hal 127-137.

[5] Kuswarno, Engkus. (2009). Metode Penelitian Komunikasi: Fenomenologi, Konsepsi, Pedoman dan Contoh Penelitiannya. Yogyakarta: Widya Padjajaran, Perpustakaan Pusat UII.

[6] Littlejohn, Stephen W. (2009). Theories of Human Communication, Belmont, California: Wadsworth Publishing Company.

[7] Miles, Mathew B and Huberman, Michael A. (1984). Qualitative Data Analysis a Sourcebook of New Methode. London: Sage Publications.

[8] Notoatmodjo, Soekidjo. (2007). Promosi Kesehatan dan Ilmu Perilaku. Jakarta: PT. Rinika Cipta.

[9] Peraturan Menteri Pertanian RI No.69 Tahun 2016 Tentang Kebutuhan dan Harga Eceran Tertinggi (HET) Pupuk Bersubsidi Untuk Sektor Pertanian Tahun Anggaran 2017. Tidak Dipublikasikan.

[10] Rachman, B. (2012). Tinjauan Kritis Dan Perspektif Sistem Subsidi Pupuk. Jurnal Litbang Pertanian, 31(3), 119-127.

[11] Ritzer, G. (1975). Sociology: A Multiple Paradigma Science. Boston: Allyn and Bacon.

[12] Ritzer, G. (2001). Sosiologi Ilmu Berparadigma Ganda. Jakarta: PT Rajawali Press.

[13] Ritzer, G. (2005). Teori Sosial Post Modern. Yogyakarta: Kreasi Wacana.

[14] Ritzer, G. (2007). Sosiologi Ilmu Berparadigma Ganda. Jakarta: PT Rajawali Press.

[15] Ritzer, George dan Goodman, Douglas J. (2007). Teori Sosiologi Modern. Jakarta: Kencana Predana Media Group.

[16] Sarnia. (2015). Polisemi Dalam Bahasa Muna. Jurnal Humanika, 151(15), 10-17. https://doi.org/10.1145 /3132847.3132886.

[17] Setiadi, Elly M dan Usman Kolip. (2011). Pengantar Sosiologi. Jakarta: Kencana

[18] Sobur, Alex. (2003). Psikologi Umum. Bandung: CV Pustaka Setia.

[19] Supraja, M. (2012). Alfred Schutz: Rekonstruksi Teori Tindakan Max Weber. Jurnal Pemikiran Sosiologi, 1(2).

[20] Tracy, Sarah J. (2013). Qualitative Research Methods Collecting Evidence, Crafting Analysis, Communicating Impact. United Kingdom: Wiley- Blackwell A John Wile \& Sns, Ltd., Publication.

[21] Turner, Bryan S. (2012). Teori Sosial Dari Klasik Sampai Postmodern. Yogyakarta: Pustaka Pelajar.

[22] Turner, Jonathan H., (1998). The Structure of Sociological Theory (Sixth Edition). USA: Wadsworth Publishing Company.

[23] Turner, S.P. (ed). (2000). The Cambridge Companion to Weber. New York: Cambridge University Press.

[24] Upe, Ambu. (2008). Sosiologi Politik Kontemporer. Kajian tentang rasionalitas Perilaku Politik Pemilih di Era Pemilihan Kepala Daerah Secara Langsung. Jakarta: Prestasi Pustaka.

[25] Vembriarto, S.T. (1984). Psikologi Sosial, Suatu Pengantar Ringkas. Yogyakarta: Yayasan Pendidikan Paramita.

[26] Wirawan, I.B. (2013). Teori-Teori Sosial dalam Tiga Paradigma. Jakarta: Kencana Prenda Media Group.

\section{AUTHOR's BIOGRAPHY}

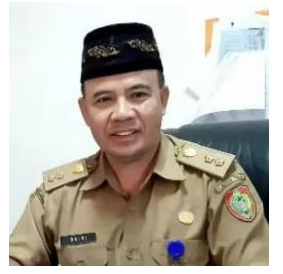

Baini, was born on May 15, 1966 in Muara Takuam Village, Pematang Karau District, South Barito Regency. Address: Bangas Permai RT. 03 / RW X, Menteng Village, Jekan Raya District, Palangka Raya City, Central Kalimantan Province. Education: Bambulung Elementary School in 1979, Bambulung Middle School in 1982, Teluk Betung High School in 1985, D / III Agriculture in Palangka Raya University in 1989, S-1 University of PGRI Palangka Raya in 1997 and S-2 MAP at Muhammadiyah University in Palangka Raya in 2016. Employment : Head of the Center for Food Crops and Horticulture Protection at the Office of Food Crops, Horticulture and Animal Husbandry of Central Kalimantan Province, Jl. Tjilik Riwut Km 6.5 Palangka Raya.

Citation: Ishomuddin, et.al. " The Meaning of Actor Social Action in Distribution of Subsidized Fertilizers in Pulang Pisau District, Central Kalimantan Province." International Journal of Humanities Social Sciences and Education (IJHSSE), vol 7, no. 4, 2020, pp. 44-51. doi: http://dx.doi.org/10.20431/2349-0381. 0704006.

Copyright: (C) 2020 Authors. This is an open-access article distributed under the terms of the Creative Commons Attribution License, which permits unrestricted use, distribution, and reproduction in any medium, provided the original author and source are credited. 